\title{
Aktivitas Antibakteri Ekstrak Etanolik Daun Juwet (Syzygium cumini (L.) Skeels) terhadap Bakteri Isolat Klinis Salmonella typhi
}

\section{Antibacterial Activity of Ethanolic Extracts of Java Plum (Syzygium cumini (L) Skeels) Leaves against Clinical Isolate of Salmonella typhi}

\author{
Rizka Dwi Rahmitasari ${ }^{1 *}$, Dewi Suryani ${ }^{2}$, Nisa Isneni Hanifa $^{1}$ \\ ${ }^{1}$ Program Studi Farmasi, Fakultas Kedokteran, Universitas Mataram, \\ Jl. Majapahit No. 62, Mataram, Nusa Tenggara Barat 83115, Indonesia \\ ${ }^{2}$ Program Studi Pendidikan Dokter, Fakultas Kedokteran, Universitas Mataram, \\ Jl. Majapahit No. 62, Mataram, Nusa Tenggara Barat 83115, Indonesia \\ *Corresponding author email: rizkadrahmitasari@gmail.com
}

Received 19-01-2020 Accepted 19-04-2020 Available online 01-07-2020

\begin{abstract}
ABSTRAK
Peningkatan kasus resistensi bakteri Salmonella typhi terhadap antibiotik mendorong penelitian tentang pemanfaatan bahan alam sebagai antibakteri alternatif. Juwet (Syzygium cumini (L) Skeels) telah terbukti memiliki aktivitas antibakteri karena mengandung fenol, flavonoid, terpenoid, tanin, saponin, dan steroid. Penelitian ini bertujuan untuk mengetahui aktivitas antibakteri ekstrak etanol daun juwet terhadap Salmonella typhi isolat klinis. Pengujian aktivitas antibakteri menggunakan kelompok uji ekstrak etanol daun juwet (variasi konsentrasi 25, 50, 100, dan $200 \mathrm{mg} / \mathrm{mL}$ ), kontrol positif (kloramfenikol) dan kontrol negatif (DMSO 10\%). Aktivitas antibakteri ekstrak daun juwet ditentukan berdasarkan diameter zona hambat, Konsentrasi Hambat Minimum (KHM), dan Konsentrasi Bunuh Minimum (KBM), yang masing-masing dilakukan dengan metode difusi sumuran, dilusi padat, dan dilusi padat. Hasil penelitian menunjukkan bahwa ekstrak etanol daun juwet memiliki daya hambat yang kuat terhadap pertumbuhan bakteri Salmonella typhi $(p<0,05)$. Zona hambat terbesar ditunjukkan oleh konsentrasi $200 \mathrm{mg} / \mathrm{mL}$ dengan diameter sebesar $19,33 \mathrm{~mm}$. Nilai KHM dan KBM ekstrak etanol daun juwet berturut-turut sebesar 25 dan 100 mg/mL.
\end{abstract}

Kata kunci: daun juwet, isolat klinis Salmonella typhi.

\section{ABSTRACT}

The increasing prevalence of Salmonella typhi resistance to antibiotics has led to a demand for new natural product-originated antibacterials. Java plum (Syzygium cumini (L) Skeels) is known as an antibacterial medicinal plant with phenols, flavonoids, terpenoids, tannins, saponins, and steroids as its active compounds. The study was 
conducted to determine the antibacterial activity of ethanolic extracts of juwet leaves against clinical isolates of Salmonella typhi. The ethanolic extracts of juwet leaves (at the concentrations of $25,50,100$, and $200 \mathrm{mg} / \mathrm{mL}$ ), positive control (chloramphenicol), and negative control (10\% DMSO) groups were established for the antibacterial activity evaluation. The inhibition zone, Minimum Inhibitory Concentration (MIC), and Minimum Bactericidal Concentration (MBC) were used as the parameters, which were determined by agar well diffusion, solid dilution, and solid dilution methods, respectively. The results showed that the ethanolic extracts of juwet leaves showed antibacterial activity against clinical isolate of Salmonella typhi $(p<0.05)$. The best inhibitory zone was shown by extract at a concentration of $200 \mathrm{mg} / \mathrm{mL}$, with a diameter of $19.33 \mathrm{~mm}$. The MIC and $M B C$ values of the extract were 25 and $100 \mathrm{mg} / \mathrm{mL}$, respectively.

Key words: clinical isolate of Salmonella typhi, juwet leaves.

\section{Pendahuluan}

Salmonella enterica serovar typhi adalah agen penyebab utama demam tifoid yang merupakan anggota dari famili Enterobacteriaceae (Elumalai et al., 2014). Penularan penyakit demam tifoid dapat melalui kontaminasi makanan dan minuman sebagai akibat dari sanitasi yang buruk (World Health Organization, 2018). Demam tifoid termasuk salah satu penyakit infeksi yang bertanggung jawab secara signifikan terhadap tingginya angka morbiditas dan mortalitas di seluruh dunia. Profil Kesehatan Indonesia tahun 2013 memperlihatkan bahwa demam tifoid termasuk dalam 10 penyakit terbanyak yang diderita oleh pasien rawat inap di rumah sakit. Angka penderita demam tifoid di Indonesia mencapai $81 \%$ per 100.000 (Departemen Kesehatan RI, 2013).

Pada beberapa tahun terakhir, pengobatan demam tifoid menggunakan antibiotik menjadi tidak efektif disebabkan resistensi oleh bakteri.
Resistensi yang terjadi pada bakteri Salmonella typhi dikenal dengan istilah Multi-drug Resistant Salmonella typhi (MDRST). Terjadinya MDRST ditandai dengan menurunnya sensitivitas bakteri terhadap antibiotik lini pertama pengobatan demam tifoid, seperti kloramfenikol, ampisilin, sulfonamide, dan tetrasiklin (Das et al., 2017).

$$
\text { Juwet (Syzygium cumini) }
$$

merupakan salah satu tumbuhan yang memiliki aktivitas antibakteri. Salah satu senyawa yang terkandung dalam daun juwet yakni eugenol yang memiliki aktivitas farmakologi sebagai antisalmonella (Ramya et al., 2012).

$$
\text { Disc diffusion termasuk salah }
$$
satu metode pengujian untuk menentukan aktivitas agen antimikroba. Menurut Hariyati et al. (2017), kekurangan dari metode disc diffusion yaitu tingkat osmolaritas larutan uji yang rendah dan konsentrasi ekstrak yang digunakan lebih sedikit. Oleh sebab itu dalam penelitian ini digunakan difusi sumuran sebagai metode dalam pengujian antibakteri. Berdasarkan latar 
belakang yang telah dipaparkan, tujuan penelitian ini yaitu mengetahui efek antibakteri ekstrak etanol daun juwet terhadap bakteri isolat klinis Salmonella typhi, serta menentukan nilai KHM (Konsentrasi Hambat Minimum) dan KBM (Konsentrasi Bunuh Minimum) ekstrak etanol daun juwet (Syzygium cumini) terhadap bakteri isolat klinis Salmonella typhi.

\section{Metode Penelitian}

Alat dan Bahan

Peralatan yang digunakan dalam penelitian ini adalah timbangan analitik (Mettler Toledo ${ }^{\circledR}$ ), rotary evaporator (Buchi), autoklaf (Tomy), Laminar Air Flow Cabinet (Esco), inkubator (Memmert), oven (Memmert), alat-alat gelas (Iwaki Pyrex ${ }^{\circledR}$ ), pelubang sumuran (cork borer), yellow dan blue tip, handcounter (VWR), dan colony counter (Stuart).

Bahan yang digunakan dalam penelitian ini adalah daun juwet, etanol $70 \%$ teknis (SCP), dimethyl sulphur oxide (DMSO) (Merck), nutrient agar (Oxoid), mueller hinton agar (Oxoid), larutan $\mathrm{NaCl}$ 0,9\% (Merck), standar 0,5 McFarland, akuades, kloramfenikol disc (30 $\mu \mathrm{g})$ (Oxoid), Kloramfenikol kapsul $250 \mathrm{mg}$ (Novachlor), larutan $\mathrm{HCl}$ (Merck), larutan $\mathrm{H}_{2} \mathrm{SO}_{4}$ (Merck), reagen Dragendroff, reagen Mayer, reagen LiebermannBurchard, serbuk $\mathrm{Mg}$, larutan $\mathrm{FeCl}_{3}$, kloroform, dietil eter, cat gram (A, B, C, D), dan minyak imersi (Merck).

\section{Jalannya Penelitian}

1. Determinasi tanaman
Determinasi juwet (Syzygium cumini) dilakukan di Laboratorium Biologi, Fakultas Matematika dan Ilmu Pengetahuan Alam, Universitas Mataram.

2. Pembuatan ekstrak

Serbuk simplisia dimaserasi dengan etanol $70 \%$ pada wadah yang tertutup rapat dengan perbandingan 1:5 (b/v). Proses maserasi dilakukan selama 24 jam dengan pengadukan setiap 1 jam pada 6 jam pertama. Ekstrak cair yang diperoleh dipekatkan dalam rotary evaporator pada suhu di bawah $60{ }^{\circ} \mathrm{C}$. Selanjutnya dilakukan pemeriksaan organoleptik dan perhitungan rendemen ekstrak kental (Juliantoni dan Dyke, 2018).

3. Skrining fitokimia ekstrak

$\begin{array}{rrr}\text { Skrining } & \text { fitokimia } & \text { dilakukan } \\ \text { terhadap } & \text { senyawa alkaloid }\end{array}$
(Simaremare, 2014), flavonoid (Gowri dan Vasantha, 2010), saponin (Departemen Kesehatan RI, 1995), polifenol dan tannin (Simaremare, 2014), terpenoid (Gowri dan Vasantha, 2010), dan steroid (Kristina et al., 2009).

4. Uji aktivitas antibakteri

Persiapan bakteri uji

Bakteri Salmonella typhi yang digunakan dalam penelitian ini adalah bakteri isolat klinis yang diperoleh dari Laboratorium Mikrobiologi, Fakultas Farmasi, Universitas Gadjah Mada. Selanjutnya bakteri isolat klinis Salmonella typhi diidentifikasi melalui pemeriksaan mikroskopis dengan metode pewarnaan Gram. Identifikasi 
bakteri Salmonella typhi dilakukan pada bulan Maret 2019 di Laboratorium Mikrobiologi, Rumah Sakit Umum Daerah Provinsi Nusa Tenggara Barat.

\section{Pembuatan larutan uji}

Pembuatan larutan uji dimulai dengan pembuatan larutan stok terlebih dahulu. Larutan stok dibuat dengan cara mengencerkan ekstrak etanol daun juwet sebanyak 1250 mg ke dalam $5 \mathrm{~mL}$ pelarut DMSO 10\%, sehingga diperoleh konsentrasi larutan stok sebesar $250 \mathrm{mg} / \mathrm{mL}$. Selanjutnya larutan uji dengan konsentrasi 25, 50, 100, dan 200 $\mathrm{mg} / \mathrm{mL}$ dibuat dengan mengencerkan larutan stok menggunakan pelarut DMSO 10\%.

Pembuatan inokulum bakteri

Biakan bakteri pada media NA diinokulasikan menggunakan ose ke dalam larutan $\mathrm{NaCl}$ 0,9\% steril hingga diperoleh kekeruhan yang sama dengan standar 0,5 McFarland atau setara dengan konsentrasi bakteri 1,5 x $10^{8} \mathrm{CFU} / \mathrm{mL}$ (Astrini et al., 2014).

Penentuan diameter zona hambat

Pengujian diameter zona hambat menggunakan metode difusi sumuran. Pada metode ini suspensi bakteri $\left(1,5 \times 10^{8} \mathrm{CFU} / \mathrm{mL}\right)$ diinokulasi pada media MHA dengan cotton swab, diinkubasi selama 10 menit, setelah itu sumur disiapkan dengan bantuan cork borer steril (diameter 6 $\mathrm{mm}$ ). Pada tiap sumuran dimasukkan masing-masing $50 \mu \mathrm{L}$ ekstrak etanol daun juwet $(25,50,100$, dan 200 $\mathrm{mg} / \mathrm{mL}), \quad$ kontrol positif (kloramfenikol $30 \mu \mathrm{g}$ ) dan kontrol negatif (DMSO 10\%). Cawan petri kemudian diinkubasi selama 24 jam pada suhu $37^{\circ} \mathrm{C}$. Data hasil diambil dari nilai rata-rata hasil pengukuran zona hambat yang dilakukan sebanyak tiga kali replikasi dengan satuan milimeter ( $\mathrm{mm}$ ) (Panjaitan et al., 2018).

Penentuan nilai KHM dan KBM

Penentuan nilai KHM dan KBM dimulai dengan pengenceran suspensi bakteri $\left(1,5 \times 10^{8} \mathrm{CFU} / \mathrm{mL}\right)$ hingga mencapai pengenceran $10^{5}$. Pengenceran tersebut digunakan berdasarkan perhitungan jumlah koloni yang berkisar antara 30-300 koloni (Mubarak et al., 2016). Pengujian KHM dan KBM dilakukan dengan metode dilusi padat yaitu Standard Plate count (SPC) yang terdiri dari empat kelompok perlakuan, satu kelompok kontrol media, dan satu kelompok kontrol antibiotik.

\section{Hasil dan Pembahasan \\ Pembuatan Ekstrak}

Sebanyak 250 gram serbuk simplisia daun juwet diekstraksi dengan metode maserasi menggunakan etanol 70\%. Pada metode ini cairan penyari akan menembus dinding sel dan masuk ke rongga sel yang mengandung zat aktif dan melarutkan zat aktif tersebut, kemudian akan keluar dari dinding sel melalui proses difusi. Cairan penyari yang digunakan adalah etanol $70 \%$ karena etanol merupakan pelarut universal dengan indeks polaritas 5,2 
sehingga berbagai senyawa baik polar maupun nonpolar dalam daun juwet seperti alkaloid, flavonoid, saponin, tanin, steroid, dan terpenoid dapat tertarik ke dalam pelarut (Pangesti et al., 2017).

Seluruh filtrat hasil maserasi diuapkan dengan rotary evaporator dan diuapkan secara manual pada suhu ruang untuk mendapatkan ekstrak kental. Ekstrak kental yang dihasilkan sebanyak 3 gram sehingga diperoleh rendemen ekstrak sebesar 1,2\%, kemudian dilakukan pengamatan organoleptis ekstrak yang bertujuan untuk memberikan pengenalan awal menggunakan panca indra dengan mendeskripsikan bentuk, warna, dan bau. Hasil uji organoleptis ekstrak etanol daun juwet dapat dilihat pada Tabel 1.

Tabel 1. Data organoleptis ekstrak

\begin{tabular}{cc}
\hline Organoleptis & Keterangan \\
\hline Bentuk & Pasta \\
Warna & Coklat tua \\
Bau & Khas ekstrak \\
\hline
\end{tabular}

Hasil Skrining Fitokimia

Hasil uji skrining fitokimia ekstrak etanol daun juwet menunjukkan bahwa ekstrak daun juwet positif mengandung senyawa di antaranya flavonoid, saponin, terpenoid, fenol, tannin, dan steroid. Namun, untuk hasil pengujian golongan senyawa alkaloid menunjukkan hasil negatif yang ditunjukkan pada Tabel 2.

Tabel 2. Hasil skrining fitokimia ekstrak etanol daun juwet

\begin{tabular}{lc}
\hline \multicolumn{1}{c}{ Pemeriksaan } & Hasil \\
\hline Alkaloid & \\
$\quad$ Pereaksi Dragendroff & - \\
$\quad$ Pereaksi Mayer & - \\
Flavonoid & + \\
Saponin & + \\
Terpenoid & + \\
Polifenol \& Tanin & + \\
Steroid & + \\
\hline
\end{tabular}

Pada penelitian ini tidak ditemukan senyawa alkaloid dalam daun juwet. Hasil tersebut berbeda dengan hasil penelitian Mere (2018) yang menyatakan bahwa ekstrak etanol daun juwet mengandung alkaloid. Pada penelitian ini tidak ditemukan adanya senyawa alkaloid dalam daun juwet karena alkaloid tidak terlarut dalam pelarut etanol 70\%. Menurut Romadanu et al. (2014), alkaloid efektif larut dalam n-heksana dan kloroform. 
Pengujian Aktivitas Antibakteri Ekstrak Etanol Daun Juwet

Hasil uji diameter zona hambat ekstrak etanol daun juwet terhadap bakteri isolat klinis Salmonella typhi diperoleh bahwa ekstrak tersebut mampu menghambat pertumbuhan dari bakteri Salmonella typhi yang ditunjukkan pada Tabel 3. Besar zona hambat memiliki korelasi positif terhadap konsentrasi ekstrak, sehingga semakin besar konsentrasi ekstrak maka zona hambat yang dihasilkan juga akan semakin besar.

Tabel 3. Hasil pengukuran diameter zona hambat

\begin{tabular}{cc}
\hline Konsentrasi Ekstrak (mg/mL) & Rata-rata Diameter Zona Hambat (mm) \\
\hline 25 & $14,67 \pm 1,15^{*}$ \\
50 & $16,67 \pm 1,15^{*}$ \\
100 & $18,33 \pm 1,53^{*}$ \\
200 & $19,33 \pm 1,53^{*}$ \\
Kontrol (+) & $32 \pm 4,00$ \\
Kontrol (-) & - \\
\hline Keterangan: Data dianalisis menggunakan uji Mann-Whitney \\
$*=$ Berbeda signifikan dengan kontrol $(+)(p<0,05)$
\end{tabular}

Data hasil pengukuran diameter zona hambat ini menunjukkan bahwa ekstrak etanol daun juwet mampu menghambat pertumbuhan bakteri isolat klinis Salmonella typhi yang ditandai dengan adanya zona hambat. Pada penelitian ini, daya hambat ekstrak etanol daun juwet pada konsentrasi 25 $\mathrm{mg} / \mathrm{mL}(14,67 \mathrm{~mm}), 50 \mathrm{mg} / \mathrm{mL}(16,67$ $\mathrm{mm}), 100 \mathrm{mg} / \mathrm{mL}(18,33 \mathrm{~mm})$, dan 20 $\mathrm{mg} / \mathrm{mL}(19,33 \mathrm{~mm})$. Berdasarkan hasil tersebut, dapat diketahui bahwa semakin tinggi konsentrasi ekstrak etanol daun juwet yang diuji, maka semakin besar juga diameter zona hambat yang terbentuk di sekeliling sumuran.

Berdasarkan hasil uji statistik Mann-Whitney, menunjukkan bahwa tiap konsentrasi larutan uji ekstrak etanol daun juwet memiliki perbedaan yang bermakna dengan kontrol positif yaitu kloramfenikol. Bahkan konsentrasi larutan uji $200 \mathrm{mg} / \mathrm{mL}$ juga memiliki perbedaan yang bermakna dengan kloramfenikol. Hal ini dikarenakan kloramfenikol merupakan antibiotik bakteriostatik berspektrum luas yang aktif terhadap bakteri Gram positif maupun negatif. Kloramfenikol aktif terhadap bakteri Neisseria meningitidis, Haemophilus influenza, Rickettsiae, Escherichia coli, Staphylococcus aureus, dan Salmonella typhi (Katzung, 2004).

Kemampuan suatu ekstrak dalam menghambat pertumbuhan mikroba dipengaruhi oleh konsentrasi dari ekstrak tersebut (Sudarmi et al., 2017). Berdasarkan hasil uji pada Tabel 3 , diameter zona hambat paling besar terhadap bakteri Salmonella typhi terdapat pada konsentrasi ekstrak 200 
$\mathrm{mg} / \mathrm{mL}$. Selain pengaruh konsentrasi, kemampuan suatu ekstrak dalam menghambat pertumbuhan bakteri juga ditentukan oleh golongan senyawa antimikroba yang dihasilkan oleh ekstrak tersebut (Ajizah, 2004). Pada penelitian ini aktivitas antimikroba daun juwet disebabkan karena adanya kandungan senyawa metabolit sekunder yaitu flavonoid, fenol, terpenoid, tanin, saponin, dan steroid.

Senyawa flavonoid memiliki dua cara dalam membunuh bakteri yaitu dengan merusak membran sel bakteri dan mendenaturasi protein sel bakteri. Mekanisme kerja senyawa flavonoid dalam merusak membran sel bakteri yaitu membentuk senyawa kompleks dengan protein ekstraseluler sehingga membran sel bakteri rusak dan diikuti dengan masuknya air yang tidak terkontrol ke dalam sel bakteri. Hal ini menyebabkan pembengkakan dan akhirnya membran sel bakteri pecah. Selain itu senyawa flavonoid memiliki kemampuan mendenaturasi protein sel bakteri dengan cara membentuk ikatan hidrogen kompleks dengan protein sel bakteri. Oleh karena itu, struktur dinding sel dan membran sitoplasma bakteri yang mengandung protein menjadi tidak stabil dan kehilangan aktivitas biologinya, sehingga fungsi permeabilitas sel bakteri terganggu dan sel bakteri mengalami lisis yang berakibat pada kematian sel bakteri (Putri, 2014).

Mekanisme kerja fenol sebagai antibakteri yaitu meningkatkan permeabilitas membran sitoplasma sehingga menyebabkan kebocoran komponen intraseluler dan koagulasi sitoplasma yang mengakibatkan lisis (Sudarmi et al., 2017). Senyawa fenol merupakan antibakteri yang bersifat bakterisidal. Senyawa fenol memiliki aktivitas antimikroba berspektrum luas terhadap bakteri Gram positif dan Gram negatif sehingga senyawa fenol secara intensif dapat digunakan sebagai desinfektan (Oliver et al., 2001). Mekanisme terpenoid yaitu bereaksi dengan porin (protein transmembran) pada membran luar dinding sel bakteri, membentuk ikatan polimer yang kuat sehingga terjadi kerusakan porin. Rusaknya porin dapat menyebabkan kurangnya permeabilitas dinding sel bakteri yang akan mengakibatkan sel bakteri kekurangan nutrisi, sehingga pertumbuhan bakteri terhambat dan mati (Cowan, 1999).

Senyawa tanin memiliki akitivitas antibakteri dengan mekanisme yaitu membentuk ikatan hidrogen dengan protein yang ada pada sel bakteri sehingga protein akan terdenaturasi dan metabolisme dari bakteri akan terganggu (Mailoa et al., 2014). Selain itu tanin dapat membentuk ikatan dengan fosfolipid yang ada di membran sel dan mengakibatkan kebocoran membran, dimana kerusakan ini dapat mencegah masuknya nutrisi yang dibutuhkan untuk pertumbuhan bakteri (Volk dan Wheller, 1988). Senyawa berikutnya adalah saponin dengan mekanisme yaitu menurunkan tegangan permukaan sehingga permeabilitas dari membran sel bakteri meningkat dan mengakibatkan kebocoran sel, sehingga senyawa 
intraseluler akan keluar (Nuria et al., 2009). Senyawa terakhir yang memberikan aktivitas antibakteri adalah steroid. Mekanisme kerja steroid yaitu merusak membran lipid sehingga liposom mengalami kebocoran dan terjadi kematian sel (Sudarmi et al., 2017).

KHM dan KBM diuji untuk menentukan besarnya kemampuan ekstrak etanol daun juwet dalam menghambat ataupun membunuh bakteri Salmonella typhi. Metode yang digunakan adalah dilusi padat dengan Standard Plate Count (SPC). Pengujian SPC dimaksudkan untuk menunjukkan jumlah mikroba yang terdapat dalam suatu bahan dengan cara menghitung koloni bakteri yang ditumbuhkan pada media agar. Prinsip dari metode SPC adalah menumbuhkan sel-sel mikroba yang masih hidup pada suatu media sehingga sel tersebut berkembang biak dan membentuk koloni-koloni yang dapat dilihat langsung dengan mata tanpa menggunakan mikroskop, dan koloni dapat dihitung menggunakan colony counter (Mubarak et al., 2016).

Ketentuan dalam pengujian menggunakan teknik SPC yaitu jumlah koloni yang digunakan berkisar antara 30-300 CFU (Colony Forming Unit)/mL dari pengenceran bakteri. Hal ini dimaksudkan agar hasil perhitungan lebih akurat (Mubarak et al., 2016). Selain itu pengenceran bakteri juga bertujuan untuk mengendalikan populasi bakteri yang digunakan dalam pengujian. Semakin besar konsentrasi suspensi bakteri maka pertumbuhan bakteri akan semakin padat sehingga kepekaannya terhadap senyawa antibakteri akan semakin lemah (Utami, 2017).

Hasil uji aktivitas antibakteri ekstrak etanol daun juwet terhadap bakteri isolat klinis Salmonella typhi dengan metode SPC menunjukkan bahwa ekstrak etanol daun juwet dapat menghambat pertumbuhan Salmonella typhi pada tiap konsentrasi (Tabel 4). Hal ini dibuktikan dengan menurunnya jumlah koloni Salmonella typhi yang tumbuh di tiap konsentrasi perlakuan. Ekstrak etanol daun juwet dengan konsentrasi $25 \mathrm{mg} / \mathrm{mL}$ memiliki kemampuan dalam menghambat pertumbuhan bakteri isolat klinis Salmonella typhi paling kecil, kemudian diikuti dengan konsentrasi $50 \mathrm{mg} / \mathrm{mL}$. Pada konsentrasi 100 dan $200 \mathrm{mg} / \mathrm{mL}$ tidak terdapat koloni bakteri yang tumbuh. Dengan kata lain, ekstrak etanol daun juwet mampu membunuh bakteri isolat klinis Salmonella typhi pada konsentrasi $100 \mathrm{mg} / \mathrm{mL}$.

Konsentrasi terkecil terjadinya penurunan pertumbuhan koloni terdapat pada konsentrasi $25 \mathrm{mg} / \mathrm{mL}$. Hasil tersebut menunjukkan bahwa KHM dari ekstrak etanol daun juwet adalah 25 $\mathrm{mg} / \mathrm{mL}$, sementara itu pada konsentrasi $100 \mathrm{mg} / \mathrm{mL}$ tidak ditemukan pertumbuhan bakteri Salmonella typhi yang berarti bahwa KBM dari ekstrak etanol daun juwet adalah $100 \mathrm{mg} / \mathrm{mL}$. Selain itu, semakin tinggi konsentrasi yang digunakan maka semakin besar kemampuannya dalam menghambat dan membunuh bakteri Salmonella typhi. Hasil penelitian yang diperoleh sesuai 
dengan hasil penelitian Natarini (2007), bahwa semakin tinggi konsentrasi yang digunakan maka semakin baik dalam menghambat mikroorganisme.

Tabel 4. Jumlah koloni bakteri pada pengujian KHM dan KBM

\begin{tabular}{cc}
\hline Konsentrasi Ekstrak $(\mathrm{mg} / \mathrm{mL})$ & Jumlah Koloni $(\mathrm{CFU} / \mathrm{mL})$ \\
\hline 25 & $1,5 \times 10^{8}$ \\
50 & $1,4 \times 10^{8}$ \\
100 & 0 \\
200 & 0 \\
Media NA & 0 \\
Kloramfenikol $(30 \mu \mathrm{g} / \mathrm{mL})$ & TBUD \\
\hline
\end{tabular}

Uji penegasan dilakukan pada konsentrasi terkecil yang masih mampu menghambat pertumbuhan bakteri. Metode yang digunakan dalam pengujian ini adalah metode difusi sumuran. Hal ini sesuai dengan penelitian Cos et al. (2006) yang menyatakan bahwa KHM didefinisikan sebagai konsentrasi terendah yang menimbulkan zona bening di sekitar sumuran. Pengujian dilakukan dengan membuat variasi konsentrasi larutan ekstrak dari konsentrasi 25, 20, 15, 10, dan $5 \mathrm{mg} / \mathrm{mL}$. Hasil pengamatan terhadap diameter zona bening menunjukkan bahwa konsentrasi 25 $\mathrm{mg} / \mathrm{mL}$ masih menunjukkan daya hambat terhadap bakteri Salmonella typhi, namun pada konsentrasi ke bawah yaitu $20,15,10$, dan $5 \mathrm{mg} / \mathrm{mL}$ tidak menunjukkan adanya daya hambat karena tidak terbentuk zona bening pada sumuran. Dengan demikian dapat disimpulkan bahwa KHM ekstrak etanol daun juwet terhadap bakteri isolat klinis Salmonella typhi adalah $25 \mathrm{mg} / \mathrm{mL}$.

\section{Simpulan}

Ekstrak etanol daun juwet (Syzygium cumini) memiliki aktivitas antibakteri terhadap bakteri isolat klinis Salmonella typhi yang ditandai dengan terbentuknya zona hambat pada konsentrasi 25, 50, 100, dan $200 \mathrm{mg} / \mathrm{mL}$ sebesar 14,67; 16,67; 18,33; dan 19,33 mm. Nilai KHM dan KBM ekstrak etanol daun juwet berturut-turut adalah 25 dan 100 $\mathrm{mg} / \mathrm{mL}$.

\section{Daftar Pustaka}

Ajizah, A. 2004. Sensitivitas Salmonella typhimurium terhadap ekstrak daun Psidium guajava. Bioscientiae, 1(1):31-8.

Astrini, D., Marlia, S.W., Ilma, N. 2014. Aktivitas antibakteri madu pahit terhadap bakteri gram negatif dan gram positif serta potensinya dibandingkan terhadap antibiotik kloramfenikol, oksitetrasiklin, dan gentamisin. Acta 
Pharmaceutica Indonesia, 39(3 \& 4):75-83.

Cos, P., Vlietinck, A.J., Berghe, D.V., Maes, L. 2006. Anti-infective potential of natural products: how to develop a stronger in vitro 'proof-of-concept'. Journal of Ethnopharmacology, 106(3):290-302.

Cowan, M.M. 1999. Plant products as antimicrobial agents. Clinical Microbiology Reviews, 12(4):564-582.

Das, S., Samajpati, S., Ray, U., Roy, I., Dutta, S. 2017. Antimicrobial resistance and molecular subtypes of Salmonella enterica serovar typhi isolates from Kolkata, India over a 15 years period 1998-2012. International Journal of Medical Microbiology, 307:28-36.

Departemen Kesehatan RI. 1995. Farmakope Indonesia. Edisi ke-4. Jakarta: Departemen Kesehatan Republik Indonesia.

\section{Departemen Kesehatan RI. 2013. Sistematika Pedoman Pengendalian Penyakit Demam Tifoid. Jakarta: Direktorat Jendral Pengendalian Penyakit dan Penyehatan Lingkungan.}

Elumalai, S., Muthu, G., Selvam, R.E.M., Ramesh, S. 2014. Detection of TEM, SHV- and CTX-M-type $\beta$ lactamase production among clinical isolates of Salmonella species. Journal of Medical Microbiology, 63:962-967.
Gowri, S.S., Vasantha, K. 2010. Phytochemical screening and antibacterial activity of Syzygium cumini (I.) (myrtaceae) leaves extracts. International Journal of PharmTech Research, 2(2):15691573.

Hariyati, T., Jekti, D.S.D., Andayani, Y. 2015. Pengaruh ekstrak etanol daun jambu air (Syzygium aqueum) terhadap bakteri isolat klinis. Jurnal Penelitian Pendidikan IPA, 1(2):31-38.

Juliantoni, Y., Dyke, G.W. 2018. Optimasi formula obat kumur ekstrak herba ashitaba (Angelica keiskei) sebagai antibakteri karies gigi. Kartika: Jurnal Ilmiah Farmasi, 6 (1):40-44.

Katzung, B.G. 2004. Farmakologi Dasar dan Klinik. Edisi 8. Jakarta: EGC.

Kristina, N.N., Kusumah, E.D., Lailani, P.K. 2009. Analisis fitokimia dan penampilan polapita protein tanaman pegagan (Centella asiatica) hasil konservasi in vitro. Buletin Penelitian Tanaman Rempah dan Obat, 20(10):11-20.

Mailoa, M.N., Meta, M., Amran, L., Natsir, D. 2014. Effectiveness of tannins extract from leaf guava (Psidium guajava L) on the growth and damage of cell morphology Escherichia coli. International Journal of Advanced Research, 2(1):908914.

Mere, J.K. 2018. Aktivitas antibakteri dari daun jamblang (syzygium cumini (I.) Skeels) asal Pulau Timor terhadap Escherichia coli Pbr322. 
Tesis. Sekolah Pascasarjana, Institut Pertanian Bogor.

Prastiyanto, M.E. 2018. Aktivitas antibakteri madu terhadap bakteri multi drug resistant Salmonella typhi dan Methicillinresistant Staphylococcus aureus. Prosiding Seminar Nasional Edusainstek, $\quad 70-77 . \quad 28$ September 2019, Universitas Muhammadiyah Semarang.

Putri, D.N. 2014. Uji aktivitas antibakteri ekstrak metanol daun kenikir (Cosmos caudatus Kunth.) terhadap bakteri Salmonella typhi. Skripsi. Jurusan Biologi, Fakultas Sains dan Teknologi, Universitas Islam Negeri Maulana Malik Ibrahim Malang.

Ramya, S., Neethirajan, K., Jayakumararaj, R. 2012. Profile of bioactive compounds in Syzygium cumini. Journal of Pharmacy Research, 5(8):45484553.

Romadanu, Siti, H.R., Shanti, D.L. 2014. Pengujian aktivitas antioksidan ekstrak bunga lotus (Nelumbo nucifera). Fishtech, 3(1):1-7.

Simaremare, E.S. 2014. Skrining fitokimia ekstrak etanol daun gatal
(Laportea decumana (roxb.)

Wedd). Pharmacy: Jurnal Farmasi Indonesia, 11(1):98-107.

Sudarmi, K., Darmayasa, I.B.G., Muksin, I.K. 2017. Uji fitokimia dan daya hambat ekstrak daun juwet (Syzygium cumini) terhadap pertumbuhan Escherichia coli dan Staphylococcus aureus ATCC. Jurnal Simbiosis, 5(2):4751.

Utami, N.A. 2017. Uji daya hambat bakteriostatik dari ekstrak tomat (Lycopersicon esculentum Mill) terhadap pertumbuhan bakteri Staphylococcus epidermidis. Skripsi. Program Studi Pendidikan Biologi, Jurusan Pendidikan MIPA, FKIP, Universitas Sanata Dharma.

Volk, W.A., Wheeler, M.F. 1993. Mikrobiologi Dasar. Diterjemahkan oleh Markham. Jakarta: PT. Gelora Aksara Pratama.

World Health Organization. 2018. Weekly epidemiological record. http://apps.who.int/iris/bitstrea $\mathrm{m} /$ handle/10665/272272/WER9 313.pdf?ua=1. Data diakses pada 16 Desember 2018. 